\title{
Teaching Innovation: Module Construction for Teaching of Arabic Language Grammar Based On Symbols (Formulas) For Secondary Schools in Malaysia
}

\author{
Mat Nawi bin Mat Jusoh, Surina binti Hamed, Hakim bin Zainal \& \\ Kaseh binti Abu Bakar
}

\begin{abstract}
This study is concerned with the learning and understanding of the grammar in the Arabic Language using symbols and simple formulas for secondary school students in Malaysia. Today, the use of symbols and formulas in education has been manifested by current research as it is not only used in language research, but also in various disciplines including science, mathematics and religion knowledge.

This study locates symbols as the main fundamentals in learning the grammar in the Arabic Language. It shows that the grammar learned can be categorized and concluded in specific symbols and identified by formulas. It is hoped that this study can both achieve and to help the students with developing their learning techniques in simple ways. As a result, students will not any longer face the problems of trying to understand grammar using the Arabic Language method.

Hence, the study method used in this paper is a practical developmental research method. (1) The first part begins with simple history about the issue of learning grammar in the Arabic Language in a simple way. Here, I will show several scholars within the field that have related and discussed their ideas in terms of facilitating the grammar learning. (2) Next, the technique of using symbols and formulas will be elaborated in various knowledge disciplines. This is to prove that learning by using symbols and formulas can help and facilitate the method of learning grammar in the Arabic Language.(3) From here, I will show several symbols and formula methods which are used in the module. I hope that it is used as an easy and simple tool or guideline to understand and master grammar in the Arabic Language.

In addition, I will use a mind map technique visual to explain a specific topic in order to give students a clearer picture. Therefore, I strongly feel that a special focus should be given in grammar when learning the Arabic Language and when using the symbols and formulas technique.

With that said, a kind of learning innovation can be explored and especially if this technique is exposed via ICT (Information and Communication Technology). I hope that this suggested technique will achieve the objective of learning grammar in the Arabic Language in a simple and effective way for students in Malaysia.

This effort would benefit mostly the Muslim children currently learning grammar in the Arabic Language because we know that the Arabic Language is practiced as a Quran Language and also a Communication Language amongst the Muslim nation.
\end{abstract}

\section{Introduction}

The Qur'an is the Book of Allah subhaanahu wa taa'ala . Every words in the Qur'an come from Allah (S) to Prophet Muhammad salla-laahu 'alai wa-aalihi wa sallam through angel Jibra'eel 'alai salam. The Qur'an is a Holy Book that was written in Arabic language. Prophet Muhammad (S) was an Arab regularly read the words of Allah (S) to muslims around him. These muslims called by sahabat radiallahu anhum were very pleased and excited to receive the words of Allah (S). They also an Arabian and the majority people in Mecca and Medina spoke Arabic. Allah (S) said in surah Yusuf : $2: 1$. 2 1hat means: “We have sent it down as an Arabic Qur'an in order that you may understand".

Ibnu Kathir wrote a famous commentary on the Qur'an named Tafsir al-Qur'an said in his tafseer: "The Arabic language is the most eloquent, plain, deep and expressive of the meaning that might arise in one's mind. Therefore, the most honorable Book, was revealed in the most honorable language, to most honorable Prophet and Messenger, delivered by the most honorable angel, in the most honorable land on earth, and it's revelation started during the most honorable month of the year, Ramadan. Therefore, the Qur'an is perfect in every respect". 2 That means is including in Arabic language.

Surah Yusuf

${ }^{2}$ Tafseer Ibnu Kathir, volume 2, page 722 
As muslims we should always be working towards getting closer to Allah (S). Learning Arabic, especially Arabic grammar can be viewed as one of the ways we can grow closer to Allah (S). Please imagine that you are praying behind one of the the imam and you are able to understand everything being recited. Of course you are likely to have greater in your prayer because of your increased understanding of the language and therefore the impact of the meaning.

\section{Objectif Recherche}

The result of research can be conclusion that : (1) uses classic way in learning process which drive our student's into confusion and immotivated condition in their learning. (2) According to this, the technique of using symbols and formulas will be elaborated in various knowledge disciplines to prove that learning by using symbols and formulas can help and facilitate the method of learning grammar in the Arabic Language.

\section{Research Problem}

According to the researcher, Syauqi Dhaif said in his book which has contents easy is Tarsier al-Nahwi al-Ta'limi : "The spoken Arabic language is very regional and the dialects are often so different that even native Arabic speakers can have difficulties speaking with other Arabic from different geographical setting." ${ }^{3}$

Ali al-Jarimi and Mustafa Amen are noted in their book, nahu wadih said: "As yet we have seen long ago that novices to learn the rules of the Arabic language, braving difficulties in studied and suffer trouble in recognizing, and we saw the books and put them in, did not take their hands to the desired end only slightly and no wonder."

If we look carefully, traditional grammar approach emphasizing is too detail and too philosophical. It is burdens and complicated the studies of grammar. The same goes to the Theory of Prediction (al-Nazoriah alTaqdirah) that does not finalize on the prediction and diversify the ways in making inflection (I'rab) based on the predicted determinants. The grammatical cases of a word can be nominative (Marfu') if it come after (A'mil rafi') and accusative (Mansub) if it come (A'mil nasbi) and so forth. Both the System of Inflection (I'rab) and the Theory of Determinants (Awamil) lead into long academic debates that have gone beyond the natural characters and initial objectives of the Arabic language grammar. ${ }^{5}$

If we look closely at this issue we found that it is not the issue of the Arab nation only, but it is the issue of the Islamic nation faced by our difficulty in learning Arabic language and problems which no way to overcome them. Ishak Mohamad Rajab says: "That the level of the Arabic Language for the students in secondary school is still weak. This problem in reading the text and they face difficulty in grammar and configuring the right sentences."

Perhaps is not exaggerate if we say that the Arabic language has gained to get attention of scholars over the centuries, is not be happen with any language in the world.

From here, we want to present the importance of preparing the module on simple and easily into our students for study Arabic grammar. Helping to arrive at a clearer understanding of how this subject should be approached and understood. On the other hand, we attempt to describe and analyze the basic features of the Arab grammarian's principles of linguistic analysis, and how these principles are applied in the study of grammatical.

On this basis, Hawamidah said in his book, al-muyassar fi qawaid al-luhgat al-arabiah: "I want to give our students and our teachers the basic way how to learn and teach Arabic grammar in a simple way from difficult to easy to fit all levels in different stages." ${ }^{, 7}$ This author said very clearly that our study of grammar has to renewal and we must give our students things that they want to know without letting something else.

\section{The Importance of Grammar in Arabic Language}

Learning Arabic grammar rules is the challenging part of learning in Arabic Language. The rules we must follow and understand to properly speak the Arabic Language. This is also to keep understand the Qur'an better is Arabic grammar. Therefore Ibn Khaldun, who pointed out the importance of grammar during his search for knowledge in his book, al-Muqaddimah ${ }^{8}$.

Abu Tayyib al-Lughawi adds: "Know that the first thing must be study in Arabic language is I'rab because many mistakes come from acknowledge this item."

\footnotetext{
${ }^{3}$ Taissir al-Nahwi al-Ta'limi : Qadiman wa Hadisan, Syauqi Dhaif, page 3

${ }^{4}$ Nahu Wadih, Ali al-Jarimi and Mustafa Amin, page 5

${ }^{5}$ Medwell Journals, 2012 by Anzaruddin et. al.

${ }^{6}$ Ishak M.R. 1992. Masalah yang dihadapi oleh Sekolah-sekolah Menengah Kebangsaan Agama di Malaysia.

${ }^{7}$ Rihab Syahir Muhammad al-Hawamidah, Muyassar fi Qawaid al-Lughat al-Arabiah, page 13

${ }^{8}$ Ibnu Khaldun, al-Muqaddimah, Beirut, Darul al-Kutub al-Ilmiah (2000), page 469-471

${ }^{9}$ Ahmad al-Tantawi, Nash'ah wa tarikh asyhari al-nuhat, Kaherah, Darul al-Maarif, page 16
} 
Below, the grammarians to attempt to express the importance of studying Arabic grammar by explaining three examples of words found indifferent places in the Qur'an.

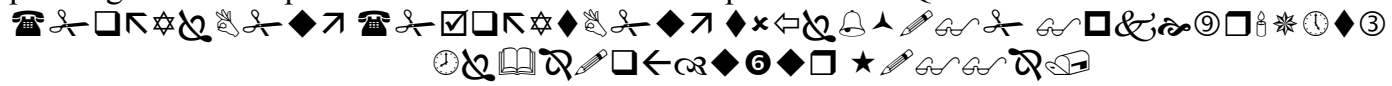

"O you who believe! Believe in Allah and His Messenger.." (Qur'an - 4:136)

The above portion of this verse carries two Arabic words that sound incredibly similar to each other, and they occur consecutively. In fact, the only difference between the two words (آمَنوا) and (آمِنو ا ( ) is changing the fathah on the ( ) to kasrah.

The change of that singe fathah into a kasrah changes the entire meaning of the same set of letters. Whereas the word (آَنو آ means "those people who have believed" and is a verb or action-word, the word ( آمِنو ا ) means, "Believe, you all!" and it is not a verb per se but rather, "a command verb". In grammatical lingo it known more formally as the "imperative verb", but the grammarians prefers referring it as the "command verb".

For next example, here is a verse from surah Ali 'Imran :

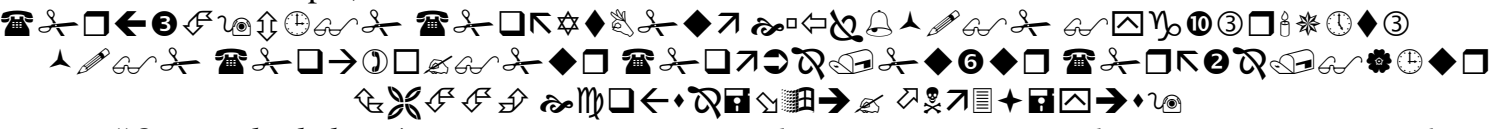

"O you who believe! Persevere in patience and constancy; vie in such perseverance; strengthen each other; and fear Allah. That you may prosper." (Qur'an - 3:200)

In the above verse, again two very similar words come right one after another. They are: (صنابُِوا) and (صنِبرُوا).

In this case, both these words are command verbs ordering a group to a certain action. However, their

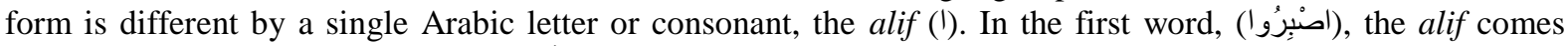
before the (صص). In the second word, (صنابُِون), the alif comes after (ص).

This single, apparently very slight, difference in writing the same set of consonants, result in two

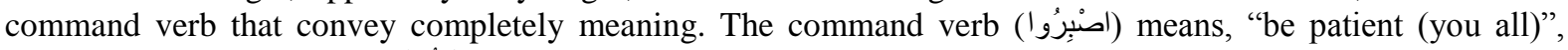
whereas the command verb (صنابِرُو ا) means, "exhort each other towards patience (you all)".

This is an obvious that powerful the language of the Qur'an. This also very beautiful it conveys different meanings by adding or moving around just one consonant/letter in a word, on vowel on it.

Now let's look at the third example. This one will present how knowledge of Arabic grammar helps us in pondering more deeply on the verses of the Qur'an, to get more detailed picture of what is being said:

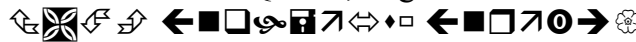

"Lay hold of him, and shackle him". (Qur'an - 69:30)

This verse of Qur'an contain two command verbs which have the pronoun (ه) appended at their end. The words,

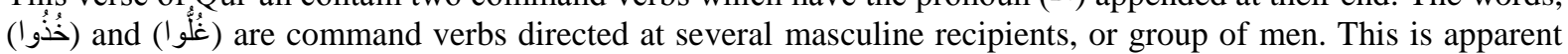
because of the $(و)$ appearing at their end.

This presents an interesting insight into this verse. The English translation says, "Lay hold of him", but analysis of the Arabic command verb (خُذُوه) reveals that, actually, several beings are being addressed to "lay hold of him", not one person.

Thus, Arabic grammar enables us to understand certain things whilst reciting or reading the Arabic text of the Qur'an directly, without needing an accompanying translation or consulting a tafsir. That grammar is the key to the study and understanding of Islamic knowledge, and unfortunately importance because a small mistake in grammar may change the meaning of a text radically.

From here, we will first learn about Arabic of grammar easily and quickly. Hence, learning the basic grammar that our students will need to be an excellent in listening, reading, speaking and writing. In this study, we provide to approach to the task of making the Arabic grammar easier to learn and study. One of the ways is using the symbols to clarify the each type of Arabic lessons.

\section{Chomsky ${ }^{10}$ Using Symbols for His Theory}

According to his book, Syntactic Structure that the "syntax is the study of the principles and processes by which sentences are constructed in particular language". He added, saying that "this theory is to provide a general method for selecting grammar for each language, given a corpus of sentences of this language."11

The language in his theory is "to be a set of sentences, each finite in length and constructed out of a finite set of elements. All natural languages in their spoken or written form are languages in this sense, since

\footnotetext{
${ }^{10}$ Noam Chomsky was born on December 7, 1928 in Philadelphia. Aged 16, in 1945 Chomsky embarked on a general program of study at the University of Pennsylvania, where his primary interest was in learning Arabic. In 1955, Chomsky obtained a job as an assistant professor at the Massachusetts Institute of Technology (MIT), spending half his time on a mechanical translation project and the other half time teaching linguistic and philosophy. Chomskyan linguistics beginning with his Syntactic Structures, a distillation of his Logical Structure of Linguistic Theory, challenges structural linguistics and introduces transformational grammar.

${ }^{11}$ Noam Chomsky, Syntactic Structures, page 11
} 
each natural language has a finite number of phonemes and each sentences is represent able as a finite sequence of these phonemes, though there are infinitely many sentences." 12

So far, we have consider this theory can assist the "linguist's task to be that of producing a device of some sort called a grammar for generating all and only the sentences of a language, which we have assumed were somehow given in advance." 13

Hence this is an interesting case of sentences that are understood in more than one way and are ambiguously represented by using the following symbols. ${ }^{14}$ As a simple example of the new form of grammar, consider the following:

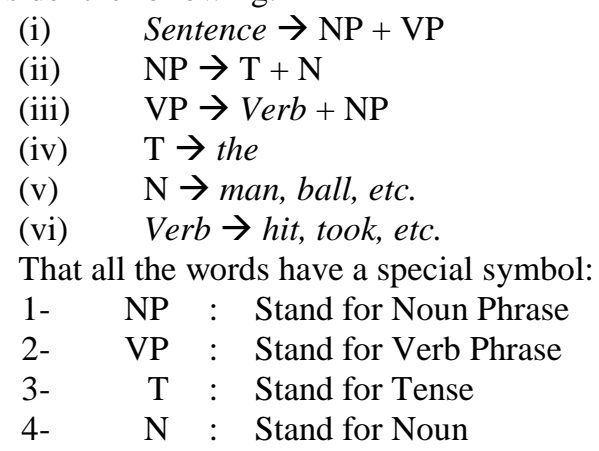

Chomsky represents the derivation in an obvious way by means of the following diagram: ${ }^{15}$

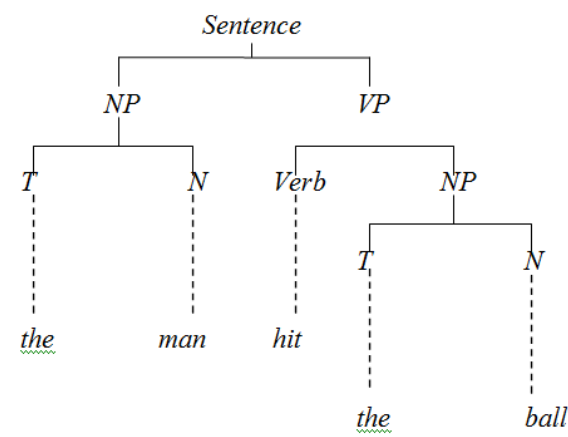

\section{Module and Programmed Catalogue Using Symbols}

This module offers the students to progress their opportunity in Arabic grammar from the level of a total beginner to lower intermediate level in the four skills (reading, listening, speaking and writing). On completion of this module, the students will be able to understand simple topic in grammar easily, respond appropriately in everyday situation, express themselves using limited rules of Arabic grammar and formulate expressions and use the target language in a limited number of contexts. So that it can be understood by basic grammatical structures for develop their skills in Arabic language like native speaker.

\section{Objectives}

The module aims to equip students with basic grounding in Arabic grammar, reading and writing. Basic grammatical structures using symbols will be covered and vocabulary will be built up in key areas of everyday communication.

Additionally, the module will introduce students to Arabic syntax. The main focus will be on reading and writing. It aims to equip students to basic sentence construction in Arabic, and acquire some vocabulary which will help them to conduct basic conversations.

\section{Learning Outcomes}

On the completion of this module students should have acquired a basic knowledge in reading and writing Arabic. They would also be able to identify the basic elements of Arabic grammar.

Students will also be able of this module, with the aid of the dictionary, to read basic Arabic texts and hold basic Arabic conversation. Students are also expected to demonstrate the ability to read basic Arabic texts.

\section{Skills Outcomes}

\footnotetext{
${ }^{12}$ Noam Chomsky, Syntactic Structures, page 13

${ }^{13}$ Noam Chomsky, Syntactic Structures, page 84

${ }^{14}$ Noam Chomsky, Syntactic Structures, page 26

${ }^{15}$ Noam Chomsky, Syntactic Structures, page 26-27
} 
On the completion of this module students will be able to understand Arabic grammatical elements, and accumulate variety of vocabulary to help them read and comprehend basic texts.

\section{Syllabus}

This module will introduce grammar fields in accusative cases and more syntactic construction, as well as continuing to expend student's vocabulary in a variety of lexical fields.

A wide range of grammatical topics will be covered, as well as wide range of basic texts for reading. Students will also be introduced to write Arabic sentences and paragraphs.

\begin{tabular}{|c|c|c|}
\hline Unit & Al-Mansūbat (المنصوبات) & Accusative Cases \\
\hline Introduction & al-Icrab (الإعراب) & The Cases \\
\hline \multirow[t]{3}{*}{ Unit 1} & Lesson 1:Mafcūl bih (المفعول به) & The object of a transitive verb. \\
\hline & $\begin{array}{l}\text { Lesson } 2 \text { : Mafcūl mutlaq (المفعول) } \\
\text { المطلق) }\end{array}$ & The internal object or cognate accusative structure. \\
\hline & Lesson 3 : Mafcül liajlih (المفعول لأجله) & $\begin{array}{l}\text { Shows the purpose of an action, usually using an indefinite } \\
\text { (مصدر). }\end{array}$ \\
\hline \multirow[t]{3}{*}{ Unit 2} & Lesson 4 : Mafcūl macah (المفعول معه) & Shows the purpose of an action. \\
\hline & Lesson 5 : Mafč̄l fih (المفعول فيه) & $\begin{array}{l}\text { Adverbial expressions of time, place and manner indicating the } \\
\text { circumstances under which an action takes place. }\end{array}$ \\
\hline & Lesson 6 : Hal (الحال) & $\begin{array}{l}\text { The circumstantial accusative to describe a condition/action } \\
\text { going on at the same time as the main action. }\end{array}$ \\
\hline \multirow[t]{2}{*}{ Unit 3} & Pre-Test: & Essentials of worship 1 \\
\hline & Post Test : & Essentials of worship 2 \\
\hline
\end{tabular}

Parts of Contents

This module contains these parts:

\begin{tabular}{|c|c|c|}
\hline Item & Parts of Contents & Explanation \\
\hline 1 & $\begin{array}{l}\text { Graphic Design } \\
\text { (الرسم البياني) }\end{array}$ & $\begin{array}{l}\text { It is using various methods to create and combine words, symbols and image } \\
\text { to create a visual representation of ideas clearly. }\end{array}$ \\
\hline 2 & $\begin{array}{l}\text { Rules of } \\
\text { Grammar (القاعدة) }\end{array}$ & $\begin{array}{l}\text { Grammar lessons with explanations and examples of usage are also included, } \\
\text { without the detailed explanations which would be added in later centuries. }\end{array}$ \\
\hline 3 & $\begin{array}{l}\text { Symbols } \\
\text { (الرموز) }\end{array}$ & $\begin{array}{l}\text { This part will provide students the opportunity to know the Arabic grammar } \\
\text { easily using the symbols. All these rules of grammar are written in symbols. }\end{array}$ \\
\hline 4 & $\begin{array}{l}\text { Text Applied } \\
\text { (النص النطبيقي) }\end{array}$ & $\begin{array}{l}\text { This part will introduce students to basic Arabic literature and culture upon } \\
\text { the Arabic texts themselves. After that will be devoted to discussion of the } \\
\text { grammar and syntactical issues of the texts. }\end{array}$ \\
\hline 5 & $\begin{array}{l}\text { Exercises } \\
\text { (التدريبات) }\end{array}$ & $\begin{array}{l}\text { The item will build upon the skills with include on Arabic grammar. This part } \\
\text { aims to enable students to develop an understanding of how of structures of } \\
\text { Arabic Grammar through the exercises was provided. }\end{array}$ \\
\hline
\end{tabular}

Translation of the Examples from Part of Module

Lesson 1 : The Complete Sentence (الجملة المفيدة)

(a) Text Applied (النص التطبيقي)

1- Sumaiyyah is beautiful.

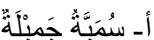

2- The Sun is rising.

3- He rode the horse.

4- The light shines in the room.

5- Clean your clothes.

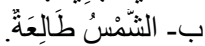

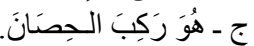

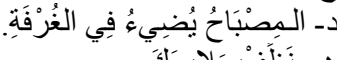

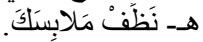

Rule 1: The composition that gives a complete meaning is called a jumble mafia (complete sentence), is also called kale (speech).

Rule 2: The complete sentence is composed of two or more words; every word is counted as part of it (the sentence).

(b) Graphic Design (الرسم البياني)

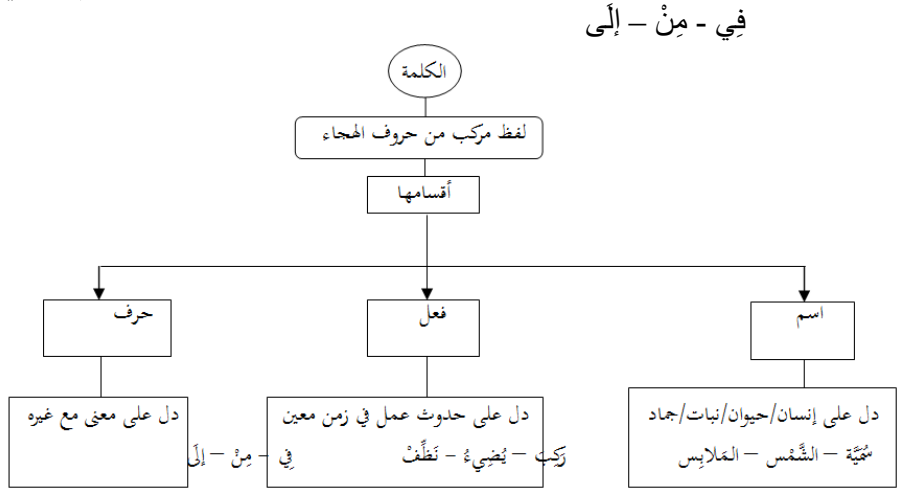

رَكِبَ - يُضِيءُ ـ نَظِّفْ 
Rule 3: Words are three types: ism (noun), fill (verb) and hard (particle).

a) The ism is every word by which a person, animal, plant, inanimate object or anything else is named.

b) The fill is every word that signifies the occurrence of an action at a particular time.

c) The hard is every word whose meaning is not completely clear without other words.

(c) Symbols (الرموز)

\begin{tabular}{|c|c|c|c|c|c|}
\hline Symbols & Translation & الكلمة & Symbols & Translation & الكلمة \\
\hline ج-ت & Broken Plurals & جمع التكسير & ج & Sentence & الجملة \\
\hline مذ & Masculine & المذكر & ج س & The nominal sentence & الجملة الاسمية \\
\hline مؤ - a - la & Feminine & المؤنث & ج ف & The verbal sentence & الجملة الفعلية \\
\hline ف & Verb & الفعل & w & Noun & الاسم \\
\hline ف ض ض & The past tense & الفعل الماضي & 5 & Subject & المبتدأ \\
\hline ف & The present tense & الفعل المضارع & $\dot{\tau}$ & Predicate & الخبر \\
\hline ف & The imperative tense & فعل الأمر & مف & Singular & المفرد \\
\hline فا & Active participle & الفاعل & مث & Dual & المثنى \\
\hline مف مف & Passive participle & المفعول & ج-ون & Regular masculine plurals & جمع المذكر السالم \\
\hline$\tau$ & Particle & الحرف & ج-ات & Regular feminine plurals & جمع المؤنث السالم \\
\hline
\end{tabular}

Rule 4: Every part of item in grammar will be using by each symbol, for example noun (w), verb (ف) and particle ( $\tau)$, etc.

(القاعدة) by using the symbols.

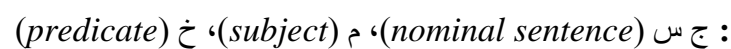

$$
\begin{aligned}
& \text { : : : (verbal sentence participle)، } \\
& \text { (passive participle) }
\end{aligned}
$$

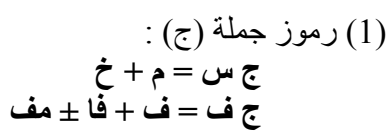

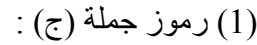

Rule 5: The nominal sentence consisting of a subject (mubtada') and its predicate (khabar) is called a jumlah ismiyyah (noun-based or nominal sentences), using symbol for subject (ק), predicate $(\dot{\gamma})$ and nominal sentence (ج $\omega)$. It's meaning that the nominal sentence must be consists of a subject and its predicate can be use by this symbol $(\dot{\tau}+r=\omega$ ج $)$.

Rule 6: The verbal sentence consisting of a verb $\left(f i^{\prime} l\right)$, subject of a verb (fa' $\left.i l\right)$ and object of a verb (maf'ul bih) is called a jumlah fi'liyyah (verbal sentence), using symbol for fi'l (ف), fa'il (ف), maf'ul bih (مف) and jumlah fi'liyyah (ج) (ج). It's meaning that the verbal sentence must be consists of a verb, subject of a verb can be use by this symbol (ج) (ج) ف in type of an intransitive verb (فعل لازم) didn't need the object of a verb, and if a verb in type a transitive verb need a object of verb.

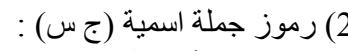

$$
\begin{aligned}
& \text { (أد) } \\
& \text { باعنبار أن (م) مبتدأ، (خ) خبر ، (إ) إعراب، (ج) جنس، (ع) (ع) عدد و(أد) معرفة. }
\end{aligned}
$$

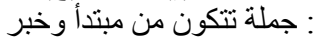

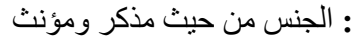

$$
\begin{aligned}
& \text { : العدد من حيث مفرد ومثنى ومنمع : }
\end{aligned}
$$

Rule 7: The mubtada' (subject of sentence) is an ism marfu' (noun in the nominative case) at the beginning of the sentence. The khabar (predicate) is also an ism marfu' (noun in the normative case) that, along with mubtada', forms a complete sentence (jumlah mufidah). Here we use the symbol (!) refer to case. It's means that the case for mubtada' and khabar are same (marfu').

Rule 8: Similar to gender that symbol we use is (ج). Nouns that can refer to both men (masculine) and women (feminine). If the mubtada' is masculine, the khabar also must be masculine and if the mubtada' is feminine, the khabar must be follow also.

Rule 9: And the same thing in count nouns that symbol we use here is ( $)$ ). It's means that the mubtada' and khabar have a gender agreement in singular, dual and plural noun. If the mubtada' is a singular noun, the khabar also must be a singular noun and so forth. It's means that the singular and plural must follow each others.

Rule 10: But it's defferent in specifies and non-specifies. Usually, we use article (الـ) in the beginning word that refers to something in specifies in particular, or something that has already been mentioned. In English is a definite article (the). An indefinite article refers to non-specifies or non-particular nouns. English has two definite article, (a) and (an), but in Arabic (usually) has no indefinite article or without article(الـ). That point we show you by this symbol (أد). It's means that the mubtada' must be specifies but not be use it in the khabar, it's must be non-specifies. For all these, we use this symbol (أد) $\left({ }^{3}\right)+{ }^{3} \mathcal{}{ }^{2} ?+!=(\dot{\tau})$ م to mention that the mubtada' and the khabar not be equal for each other. 


\section{Conclusion}

Learning Arabic can be a challenging, especially in grammar, but the reward is great. Once the students begin to appreciate to unique beauty and richness of this great language. As we said in the beginning, Arabic language of worship, prayers are read in Arabic, and the international greeting between Muslims is in Arabic. When we learn Arabic grammar that means we encouraged to enable our students to read al-Qur'an and improve their understanding of it. Knowledge of Arabic is the best tool for them to understand what Islam is about. It also helps in building positive interaction with them and other Muslims countries.

Thus, we must provide the student how to learn Arabic grammar using the easy way including the method we are use it and the module that we had been proved for them. In fact, the Arabic grammar is not the difficult subject like many people said about it, but it's the funny subject and the simpler thing. The students of Arabic grammar are therefore advised to concentrate on the Arabic terms and not to worry so much. This module has provided them for the benefit of those who are already familiar with the grammatical terms of the primary level.

\section{References}

[1]. Al-Qur'an al-Karem

[2]. Abdul Hamed. 1999. Istiratijiyyah al-Tadriis wa al-Taalim. Cairo : Dar al-Fikri al-Arabi.

[3]. Abdul Halem Ibrahem. 2007. al-Muwajjih al-Fanni li Mudarrisi al-Lughat al-Arbiyyah. Cairo : Dar al-Maarif.

[4]. Abdul Karem Khalifah. Tarsier al-Arabiyyah baina al-Qadim wa al-Hadis. Mansyurat Majma' al-Lughat al- Arabiyyah al-Urduni.

[5]. Ahmad Qadur. 2001. Lisaniyyah wa Afaaq al-Dars al-Lughawi. Damsyiq : Dar al-Fikr.

[6]. Al-Jarim Ali \& Mustafa Amen. 2004. Al-Nahwu al-Wadhih fi Qawaid al-Lughat al-Arabiyyah li al-Madaris al- Ibtidaiyyah. Beirut : al-Maktabah al-Lughawiyyah. (Translation by Usama Hasan at Al-Tawhid College, London).

[7]. Al-Rajihi Abduh. 1986. Al-Nahwu al-Arabi wa al-Dars al-Hadis. Beirut: Dar al-Nahdhah al-Arabiyyah.

[8]. Ahmad al-Tantawi. Nash'ah wa Tarikh Asyhari al-Nuhat, Cairo : Darul al-Maarif.

[9]. Chomsky, N. 1971. Syntactic Structures. $9^{\text {th }}$ Ed. Paris : The Hague.

[10]. Ibnu Kathir Al-Dimasyqi. 1988. Tafsiir al-Qur'an al-Azim. Beirut : Dar al-Kutub al-Ilmiyyah.

[11]. Ibnu Khaldun. 2000. Muqaddimah Ibni Khaldun. Beirut : Dar al-Kutub al-Ilmiyyah.

[12]. Hasan Al-Asadi. 2007. Mafhum Jumlah Inda Sibawih. Beirut : Dar al-Kutub al-Ilmiyyah.

[13]. Hussain Majdi. 2010. Tarikh al-Nahwi al-Arabi. Iskandariah : Muassasah Hauris al-Dauliyah.

[14]. Ishak M.R. 1992. Suntingan Ismail Ab. Rahman. Masalah yang dihadapi oleh Sekolah-sekolah Menengah Kebangsaan Agama di Malaysia. Bangi : Penerbit Universiti Kebangsaan Malaysia.

[15]. Mustafa Ibrahim. 1992. Ihya' al-Nahwi. Cairo.

[16]. Rihab Al-Hamidah. 2009. Al-Muyassar fi Qawaid al-Lughat al-Arabiyyah. Oman : Dar Safa' li al-Nashr wa al- Tauzie'.

[17]. Rushdi Taimah. 2001. Manahij Tadriis al-Lughat al-Arabiyyah bi al-Taalim al-Asasi. Cairo : Dar al-Fikri al-Arabi.

[18]. Syauqi Dhaif. Tarsier al-Nahwi al-Ta'limi Qadiman wa Hadisan maa Nahji Tajdidihi. Cairo : Dar al-Maarif. 